\title{
Aging among persons with invisible disorders: the importance of patient organisations
}

\author{
Vigdis Hegna Myrvang ${ }^{*}$, Kirsten Thorsen \\ From 5th European Conference on Rare Diseases (ECRD 2010) \\ Krakow, Poland. 13-15 May 2010
}

The aim of the study is to provide information about aging and the need for services among persons with Marfan syndrome. Health and welfare service providers need research based knowledge to offer this new category of elderly multidisciplinary help and counselling along the life course. There is a lack of knowledge about aging among people with a rare diagnosis and how they manage their disability in daily life during the life course. Advances in medical treatment have greatly improved the outcomes for persons with rare diagnoses, among others persons with Marfan syndrome. Many now reach an advanced age.

Marfan syndrome may not cause any recognisable impairment, but aging and increasing health problems create challenging situations in daily life. Information about the condition via patient organisations or centres with special competence is important for daily life, health condition, self image and identity. Norway has a special model with 16 national centres for rare diseases, supporting better quality of life. But there is little knowledge about the ageing processes.

\section{Methods}

Qualitative group interview with eight persons who have Marfan syndrome and qualitative in-depth interviews with ten persons having Marfan syndrome ( $>40$ years of age) are transcribed. Life course experiences are analysed with a focus on the need for information, the impact of participation in patient organisations and support from the centres.

\footnotetext{
*Correspondence: vigdis.h.myrvang@aldringoghelse.no Norwegian Centre for Research, Education and Service Development, Division of Internal Medicine, Ullevaal University Hospital, Oslo, N-0407, Norway
}

\section{Results}

The findings show the importance of having a «normal» life course, work and activities. For persons with Marfan syndrome biological and physiological changes which originate from the disorder play together with physical changes connected to ageing. The patient organisation and the national centre help the person managing challenges in daily life and the health situation in many ways. The study reveals the difficult balancing needed to function «normally» and at the same time accepting the diagnosis and its life course consequences.

Published: 19 October 2010

doi:10.1186/1750-1172-5-S1-P17

Cite this article as: Myrvang and Thorsen: Aging among persons with invisible disorders: the importance of patient organisations. Orphanet Journal of Rare Diseases 2010 5(Suppl 1):P17.

\author{
Submit your next manuscript to BioMed Central \\ and take full advantage of: \\ - Convenient online submission \\ - Thorough peer review \\ - No space constraints or color figure charges \\ - Immediate publication on acceptance \\ - Inclusion in PubMed, CAS, Scopus and Google Scholar \\ - Research which is freely available for redistribution \\ Submit your manuscript at \\ www.biomedcentral.com/submit \\ BioMed Central
}

